\begin{tabular}{|l|l|l||}
\hline \multicolumn{2}{|c|}{ PublisherInfo } \\
\hline \hline PublisherName & $:$ & Palgrave Macmillan UK \\
\hline \hline PublisherLocation & $:$ & London \\
\hline \hline PublisherImprintName & $:$ & Palgrave Macmillan \\
\hline \hline
\end{tabular}

\title{
Patterns of pay: results of the Annual Survey of Hours and Earnings, 1997 to 2006
}

\begin{tabular}{|c|c|c|}
\hline \multicolumn{3}{|c|}{ ArticleInfo } \\
\hline ArticleDOI & \multicolumn{2}{|c|}{ 10.1057/palgrave.elmr.1410028 } \\
\hline ArticleCategory & \multicolumn{2}{|l|}{ Feature } \\
\hline ArticleFirstPage & \multicolumn{2}{|l|}{44} \\
\hline ArticleLastPage & \multicolumn{2}{|l|}{51} \\
\hline \multirow{2}{*}{ ArticleHistory } & RegistrationDate & $2007-2-16$ \\
\hline & OnlineDate & $2007-2-16$ \\
\hline ArticleCopyright & \multicolumn{2}{|c|}{ Crown copyright 2007} \\
\hline
\end{tabular}


Clive Dobbs, ${ }^{\text {Affl }}$

Aff1 Office for National statistics

\section{Presents summary analyses, comparing them with the 2005 results, for a range of variables.}

The Annual Survey of Hours and Earnings (ASHE) is the Office for National Statistics' main source for information on thedistribution of earnings. It is the most detailed and comprehensive source of national information on levels of earnings,make-up of total earnings and distribution of the earnings of individual employees.

The first few sections of this article present summary analyses (overall medians, make-up and distribution ofearnings) from the results of the 2006 ASHE, comparing them with the 2005 results (and where relevant the 1997 to2005 back series). While these figures are of interest, they can hide wide variations between different industries, occupations,regions and age groups. The concluding sections of the article give summary analyses of each of these factors.

The Full Text of this article can be found on the National Statistics website (http://www.statistics.gov.uk/elmr/02_07/downloads/ELMR02_07Dobbs.pdf). 